\title{
Adatok a Mecsek fullánkos hártyásszárnyú (Hymenoptera, Aculeata) faunájához
}

\author{
JÓZAN ZSOLT
}

\author{
H-7453 Mernye Rákóczi F. u. 5.
}

e-mail: jozan.zsolt@citromail.hu

Józan Zs.: Additional data to the knowledge of the Aculeata fauna of the Mecsek mountains (Hungary, SouthTransdanubia).

Abstract: In the latest decades, author collected more Aculeata species in the Mecsek Hills which are listed in this paper. Those species are also included which become known in this mountainous region during the revision of the Hungarian Chrysididae fauna. Chrysis taczanovskii (Chrysididae) is new to the fauna of Hungary. In Hungary, rare species are: Pseudospinolia uniformis (Chrysididae), Tachysphex plicosus (Crabronidae), Heriades rubicola, Hoplitis scutellaris (Megachilidae).

Keywords: Hymenoptera, Aculeata, faunistics, new records, rare species

\section{Bevezetés}

A szerző és felesége több mint öt évtizede gyüjti a Mecsekvidéken a fullánkos hártyásszárnyúakat. A terepmunka mintegy 80-100 napon 22 település közigazgatási területén történt. A gyüjtések eredményei eddig három publikációban kerültek értékelésre (JóZAN 1996, 2002, 2006a). Az utóbbi évek gyüjtései során néhány újabb faj példányait fogták a hegység területén. A közelmúltban Muskovits József elvégezte a hazai fémdarázs fauna revízióját. A fémdarazsak határozókulcsát és lelőhelyeit tartalmazó publikációja kéziratos formában áll rendelkezésünkre (MusKoviTs et al. manuscript). Ennek nyomán lehetővé vált a Mecsekvidéken gyüjtött Chrysididae anyag revideálása is. Az alábbi jegyzékben közöljük a Mecsek faunájára új, illetve néhány ritka faj lelöhelyi adatait és a fajok elterjedésének és ökológiai igényeinek jellemzőit. A magyarországi lelőhelyek számbavételénél a Rippl-Rónai Múzeum (Kaposvár) és a Magyar Természettudományi Múzeum gyüjteményében található példányokat vesszük figyelembe.

\section{Eredmények}

\section{Chrysididae: Elampini}

Cleptes splendidus (Fabricius, 1793) - Melegkedvelö holomediterrán faj. Magyarországon tizenöt lelöhelye ismert. Ezek egy kivétellel a Dunántúlon vannak. A Magyar Természettudományi Múzeum gyüjteményében található egy Pécsen gyüjtött példány is. 
Elampus sanzii Gogorza, 1887 - Melegkedvelő paleaktikus faj. Mintegy két tucatnyi hazai lelöhelye zömmel a Kiskunságon található, öt a Dunántúlon van. Ezek egyike Nagyárpád (coll. MTM)

Elampus soror (Mocsáry, 1889) - Pécs: Gyükés 1971. VII. 12. 1 hím (leg. Józan Zs.). - Ökológiai igényei és elterjedési jellege előző fajhoz hasonlóak. 24 magyarországi lelőhelye Tiszaberceltől és Tompától Visegrádon át Keszthelyig és Pécsig található. DélDunántúlon négy helyröl került elö.

Hedychridium mediochrum Linsenmaier, 1987 - Cserkút: Dulimán dülö 2013. VII. 5. 1 nőstény (leg. Tóth S.). - Melegkedvelő mediterrán elterjedési jellegü fémdarázs. Harminc magyarországi lelöhelyeinek kétharmada a Dunántúlon van.

Holopyga jurinei Chevrier, 1862 - Pécs: Tettye 2008. VII. 10. 2 hím (leg. Józan Zs.). - Melegkedvelő palearktikus faj. A 24 hazai lelöhelyének zöme a Kiskunságon és környékén valamint a Dunántúl déli részén helyezkedik el.

\section{Chrysididae: Chrysidini}

Chrysis consanguinea prominea, Linsenmaier 1959 - Melegkedvelö, nyugat-palearktikus területeken elterjedt fémdarázs. A viridula-fajcsoport tagja. A Magyar Természettudományi Múzeum gyüjteményében pécsi lelöhelye is van. Két tucatnyi hazai gyüjtőhelye Dévaványától Kőszegig, Gyöngyöstől Vácdukán át Pécsig található.

Chrysis illigeri Wesmael 1839 - Pécsvárad: Haraszt 1989. VII. 7. 1 nőstény (leg. Józan Zs.). - Nyugat-palearktikus területeken elterjedt melegkedvelő faj. Magyarországon szélesen elterjedt, túlnyomórészt a homokvidékeinken élő fémdarázs.

Chrysis indigotea Dufour \& Perris 1840 - Melegkedvelő palearktikus fémdarázs. Harmincnál valamivel több hazai lelőhelyének egyike Pécs (coll. MTM). A gyüjtőhelyek mintegy fele Dél-Dunántúlon van.

Chrysis mediadentata Linsenmaier, 1959 - Kovácsszénája: belterület 2004. VIII. 5.1 nőstény (leg. Józan Zs.). - Harmincnégy hazai lelöhelyről ismerjük. Ezek Bátorligettől Mosonmagyaróvárig és Villányig szóródnak. Dél-Dunántúlon kilenc helyen gyüjtötték.

Chrysis mediata Linsenmaier, 1951 - Abaliget: belterület, tó környéke; Hosszúhetény: Püspökszentlászló; Komló: Sikonda; Kővágószőlős: Cigó; Magyaregregy: Egregyivölgy; Mánfa: belterület; Pécs: Tettye; Pécsvárad: Gesztenyés; Zengővárkony: belterület. (leg. Józan Zs., leg. Sasvári M.). - Széles türéshatárú nyugat-palearktikus fémdarázs. Magyarországon az egyik leggyakoribb Chrysis faj. Dél-Dunántúlon majdnem száz lelőhelyen gyüjtöttük. A Mecsekben előkerült példányait tévesen rutiliventris-nek determináltuk (JóZAN 2006).

Chrysis pseudobrevitarsis Linsenmaier, 1951 - Komló: Sikonda 1988. VIII. 7. 1 nőstény (leg. Józan Zs.). - Nyugat-palearktikus, feltételezhetően melegkedvelö állat. Hazánkban mintegy harminc helyen került elö. Ebböl a Rippl-Rónai Múzeum gyüjteményében tizenhat helyről vannak példányai.

Chrysis rutiliventris Abeille, 1879 - Pécs: Tettye 1972. VII. 6. 1 nőtény (leg. Józan Zs.). - A harminchat magyarországi lelőhelyéből nyolc jut Dél-Dunántúlra. Ezek a Zempléni-hegységtől Csornáig és a Mecsekig találhatók meg.

Chrysis solida Haupt, 1956 - Pécs: Tettye 1972. VII. 20. 1 nőstény, 1973. VII. 6. 1 nőstény (leg. Józan Zs.). - Nyugat palearktikus melegkedvelő fémdarázsfaj. Hazánkban huszonhat helyen gyüjtötték Járdánházától a Mecsekig és Fenyőfőig. A Rippl-Rónai Múzeum gyüjteményében található példányok ebből húsz lelőhelyet képviselnek.

Chrysis subsinuata Marquet, 1879 - Abaliget: belterület 2014. VII. 2. 1 hím; Hosszúhetény: belterület (leg. Józan Zs.). - Melegkedvelő pontomediterrán elterjedési jellegü fémdarázs. Húsz hazai lelöhelyének zöme a Dunántúlon van. 
Chrysis taczanovskii Radoszkowski, 1876 - Abaliget: belterület, 2014. VII. 2. 1 nőstény (leg. Józan Zs.), 2017. VI. 9. 1 hím (leg. Sasvári M.); Kovácsszénája: belterület 2004. VIII. 5. 1 nőstény. (leg. Józan Zs.). - A mediterrán tájakon és Közép-Európa déli területein előkerült Chrysis faj. Magyarországon elsőként a szerző gyüjtötte a Duna-Dráva Nemzeti Park faunisztikai kutatása során. Ezeket marginata-ként daterminálta. Az utóbbi években végzett revízió során a két faj példányainak elkülönítése megtörtént. Az utóbbi évtizedekben egyre több helyen sikerült gyüjteni. Eddig huszonhét dél-dunántúli lelöhelyen került elő. Többségük a Zselicben. Gyurkovics Henrik Szegeden találta meg (szóbeli közlés). A példányok - hasonlóan a többi Chrysis fajhoz - régi épületek vályog- és vakolatlan téglafalazatán kerültek elö. Itt fészkelnek a gazdaállataik is.

Chrysura austriaca (Fabricius, 1804) - Hüvösebb klímájú élöhelyeket kedvelő palearktikus faj. A Magyar Természettudományi Múzeum gyüjteményében egy Mecseknádasdon gyüjtött példány is található. Magyarországon a Szerencsi-dombságtól az Örségig, valamint a Börzsönytől Tompáig közel húsz lelőhelyről került elő.

Chrysura filiformis (Mocsáry, 1889) - Pécsvárad: belterület északi részén (N 46.16.55.70, E 18.40.68.60) 1992. V. 2. 1 nőstény (leg. Józan Zs.). - A mediterráneum keleti részén elterjedt melegkedvelő fémdarázs. Tizenhét hazai lelőhelyét a Dunántúlon találjuk a Kisalföldtől Budapestig és a Mecsekig.

Pseudospinolia uniformis (Dahlbom, 1854) - Magyarszék: a ligeti müút kezdeténél (N 46.21.80.81, E 18.19.18.65) 2016. V. 21. 3 nőstény (leg. Józan Zs.). - Melegkedvelö pontomediterrán faj. Első hazai előfordulását a Mecsekből Óbányáról közöltük. Az utóbbi évtizedben gyüjtöttük a Zselicben (Almamellék: Sasrét, Szenna), KülsőSomogyban (Balatonszemes, Köröshegy). Kovács-Hostyánszki Anikó a Hevesi-puszták TK kutatása során számos példányát csapdázta Besenyőtelek, Mezőtárkány és Poroszló határában.

\section{Sphecidae}

Isodontia mexicana (Saussure, 1867) - Pécs: Bárány-tető 2008. VII. 14. 1 nőstény (leg. Józan Zs.). - Észak-Amerikából került Európába. Az utóbbi évtizedekben invazív módon terjedt el Dél-Európában majd Közép-Európában. Néhány éve megtalálták Nagy-Britanniában és Ukrajnában is. Első hazai előfordulását az Őrség kutatása során igazoltuk (Szarvaskend). A hazai előfordulásairól eddig két közleményben számoltunk be (JÓZAN 2006b, 2010). Megtalálták Szombathelyen és Bozsokon is. Dél-Dunántúlon egyre több helyen gyüjtöttük. Eddig huszonöt lelöhelyét ismerjük. A bizonyító példányok a Rippl-Rónai Múzeum (Kaposvár) gyüjteményében vannak.

\section{Crabronidae}

Tachysphex plicosus (Costa, 1867) - Orfü: szennyvíztisztító környékén (N46.57.90, E18.13.48) 2014. VII. 2. 2 nőstény (leg. Józan Zs.). - Mediterrán faj, Dél-Európában Franciaországtól a Balkán-félszigetig és Romániáig ismertek előfordulásai. Előkerült Kis-Ázsiában és Azerbajdzsánban. Afrika területén Marokkóban, Egyiptomban és Szudánban fordult elő. Adriai-tenger partján Crikvenicából említik előfordulását (Pulawski 1971). Első hazai lelőhelye szintén a Mecsekben Pécsváradon vált ismertté (JÓZAN 2002).

\section{Andrenidae}

Andrena ventricosa Dours, 1873 - Magyarhertelend: településtől dél felé $1 \mathrm{~km}-\mathrm{re}(\mathrm{N}$ 46.17.94.17, E 18.15.16.49) 2017. VII. 5. 1 nőstény 2 hím. - Melegkedvelő ritka bányászméh fajunk. Észak-Afrika földközi-tengeri partvidékén, Dél-Európában, KözépEurópa melegebb klímájú tájain, Nyugat-Ázsiában a Kaspi-tengerig terjed areája, de 
Szibéria déli részén is megtalálták. Magyarországon hat régi lelőhelyét ismerjük (MóczÁr L. \& Schwarz M. 1972). A szerző Külső-Somogyban három, a Zselicben négy és a Bakonyban három helyen gyüjtötte. A Mecsekben eddig csak Óbányán találtuk meg. Az utóbbi két évtizedben csak az itt közölt helyen fogtuk.

\section{Melittidae}

Macropis frivaldszkyi Mocsáry, 1878 - Cserkút: Dulimán-dülö 2013. V. 18. 3 hím (leg. Józan Zs.). - Melegkedvelő pontokaszpikus félgömbhasú méh. A Mecsekben két lelöhelyét közöltük a Misina környékéről (JózAN 2006a). Ez az újabb lelőhely a hegység déli hegylábi övezetében található. A faunakatalógusban (MóczÁr 1957) mindössze négy hazai lelöhelye található, köztük egy 19. századi pécsi is van. Dél-Dunántúlon a Mecseken kívül csak a Zselic egy pontján (Almamellék: Terecseny) találtuk meg.

\section{Megachilidae}

Heriades rubicola Pérez, 1890 - Orfü: belterület 2017. VII. 5.1 nőstény 14 hím (leg. Józan Zs.). - Melegkedvelő mediterrán faunaelemünk. Hazánkban az utóbbi évtizedekben került elő. A szerző gyüjtései során előkerült a Bakony-vidék, a Kiskunság és DélDunántúl néhány pontján. A Mecsekben ez az első lelőhelye.

Hoplitis scutellaris (Morawitz, 1868) - Cserkút: Dulimán dülő 2013. VI. 18. 2 nőstény 1 hím, 2017. V. 29. 1 hím; Pécs: Tettye 2017. V. 29. 1 hím (leg. Józan Zs.) - Ritka mediterrán faliméh faj. Közép-Európában csak Szlovákia déli részén és Svájcban került elö (WARNCKE 1986). A szerző az Isztriai-félszigeten és Krk szigetén többfelé gyüjtötte (JÓZAN 2009). Magyarországon elsőként a Balaton-felvidék két pontján találtuk meg: Balatonfüred Tamás-hegy, Balatonfüzfö uszoda környéke (JózAN 2017).

\section{Apidae}

Nomada nobilis Herrich-Schaeffer, 1839 - Magyarszék: ligeti müút kezdeténél (N 46.21.80.81, E 18.19.18.65) 2016. V. 21. 1 nöstény (leg. Józan Zs.); Pécs: Dömörkapu 2017. V. 29. 1 hím (leg. Sasvári M.). - A mediterrán elterjedési jellegü melegkedvelő darázsméh faj. Magyarországon ritka, mintegy tucatnyi lelőhelyének többsége az Alföldön található (MóczÁR L. \& Schwarz M. 1968). A szerző a Mecseken kívül gyüjtötte a Bakonyvidéken is (Balatonfüred, Hegymagas, Porva, Tihany). A hegységben régebben már előkerült Magyarszék déli határában (JózAN 1996). 


\section{Irodalom}

JózAN Zs. 1996: A Mecsek méhszerü faunája (Hymenoptera, Apoidea). - A Janus Pannonius Múzeum Évkönyve 40(1995): 29-43.

JózAN Zs. 2002: A Mecsek kaparódarázs faunájának (Hymenoptera, Sphecoidea) faunisztikai, állatföldrajzi és ökofaunisztikai vizsgálata. - Natura Somogyiensis 3: 45-56.

JózAN Zs. 2006a: A Mecsek fullánkos hártyásszárnyú faunája (Hymenoptera, Acueata). - Folia Comloensis 15: $219-238$.

JózAN Zs. 2006b: Adatok Dél-Dunántúl fullánkos hártyásszárnyú (Hymenoptera, Aculeata) faunájának ismeretéhez. - Natura Somogyiensis 9: 279-288.

JózAN Zs. 2009: Contribution to the knowledge of the Croatian Aculeata fauna (Hymenoptera, Aculeata) Natura Somogyiensis 15: 159-180.

JózAN Zs. 2010: Újabb fullánkos hártyásszárnyú (Hymenoptera, Aculeata) fajok Somogyból. - Natura Somogyiensis 17: 251-256.

JózAN Zs. 2017: A balatonfüredi Tamás-hegy fullánkos hártyásszárnyú (Hymenoptera, Aculeata) faunája. Natura Somogyiensis 30: 47-70.

Móczár L. \& Schwarz, M. 1968: A Nomada-, Ammobates-, Pasites- és Parammobatodes nemek faunakatalógusa (Cat. Hym. XXIII.) - Folia entomologica hungarica XXI/23: 339-360.

MóczÁR M. 1957: A hazai földiméh-félék (Melittidae) faunakatalógusa és etológiai adatai. - Folia entomologica hungarica X/25: 459-471.

Muskovits J., RAhmé N. \& SzőKe V.: Magyarország fémdarazsai (Hymenoptera, Chrysididae). - (kézirat)

PulavsKI, W. 1971: Les Tachysphex Kohl (Hym. Sphecidae) de la region paleartique occidentale et centrale.Zaklad Zoologii Systematycznej i Doswiadczalnej Polskiej Akademii Nauk, Panstwowe Wydawnictwo Naukowe: pp. 464.

Warcke, K. 1986: Die Wildbienen Mitteleuropas, ihre gültigen Namen und ihre Verbreitung. - Entomofauna, Zeitschrift für Entomologie, Suppl. 3: 1-128. 
